Acheson Roberts, L. and Sterling, C. 2017. "Entangled Concepts and Participatory Practices across Archaeology, Heritage and Art”. Creative Archaeologies Forum: Beyond Art/Archaeology. Journal of Contemporary Archaeology 4.2: 130-138.

\title{
Entangled Concepts and Participatory Practices across Archaeology, Heritage and Art
}

\section{Leah Acheson Roberts}

University College London, UK

leah.roberts@ucl.ac.uk

\section{Colin Sterling}

University College London, UK

c.sterling@ucl.ac.uk

\section{Introduction}

Calls for interdisciplinary research and practice across the humanities and social sciences are hardly new, and neither are the complications that seem to beset such endeavours. As Roland Barthes declared as early as 1971, "the interdisciplinarity which is today held up as a prime value in research cannot be accomplished by the simple confrontation of specialist branches of knowledge" (Barthes 1977, 155, emphasis in original). Instead, what is required is a breaking down of "old disciplines" in the process of encountering "new objects" and "new languages" (Barthes 1977, 155): engagements that transcend traditional subject boundaries and extend conceptual horizons. Ultimately, Barthes proposed that true interdisciplinarity begins with an "unease in classification", and it is only from this moment that a "certain mutation" can be detected.

As this forum makes clear, archaeology and art are currently in the process of just such a mutation, marked by a "creative turn" in the former and a parallel "archaeological turn" in the latter. The very terms "archaeologist" and "artist" have become difficult to classify under these circumstances, with a commingling of methods, questions, approaches and objects of study dissolving hard disciplinary boundaries. In this context, archaeology - and indeed heritage - are open to a critical-creative reimagining, guided by the unique perspective on the world brought to bear in and by these fields. The projects that emerge from this milieu may evoke art and creativity explicitly or quietly, while also actively confronting a broad range of "archaeologies" and "heritages" that take us far beyond outmoded positivist perspectives. "The artistic", meanwhile, can find in the foundational practices of archaeologists and heritage professionals the inspiration for new ways of conceiving and constructing work, and in so doing - consciously or otherwise - contribute to a critique of "the archaeological" itself. Thus the "creative turn" may be best understood as a continuing process of exchange and transfiguration across fields: a 
feedback loop of concepts and practices which, at its most effective, helps reorientate the very fields in which these new activities take place.

With specific reference to the Archaeology/Heritage/Art (AHA) Research Network a loosely defined constellation of academics, events and activities established by the authors in February 2014 to interrogate precisely these concerns - this short paper sketches out the kinds of structures and practices that may be deployed to shape more experimental and process-led work. While exchanges between archaeology, heritage and art can take many forms (e.g. artistic responses to museum collections, interpretive artworks produced by archaeologists, sculptural interventions in heritage spaces), we contend that the most successful examples display two key qualities: a transdisciplinary entanglement of concepts and questions and - related to this but working at a quite different level - grounded participation across the fields in question. In so doing, we champion collaborative projects that work towards the realisation of a more socially relevant and engaged academy undeterred by antiquated subject boundaries.

\section{Entangled Disciplines}

The ever-evolving interrelationship of archaeology, heritage and art resists any simplistic characterisation (Wickstead 2013, 561). Across common themes such as materiality, ruination, authenticity, memory and the archive, the fields coalesce, contradict or destabilise one another - often all at once. The sheer diversity of such articulations can be partly explained by a broader seismic shift towards interdisciplinarity in the arts, humanities and sciences. At the same time, all three domains have become attuned to new audiences and alternative methodologies. Archaeology has become increasingly pluralist, engaging with non-archaeologists and embracing creative practices (Graves-Brown et al. 2013, 2), while heritage is now routinely characterised as an affective phenomenon more closely aligned to future making than past gazing (see Waterton and Watson 2014; Harrison 2015). Against this backdrop, art practice has found great inspiration in the museum, the excavation and the archive as spaces of critical enquiry (Russell 2013, 313). Much of this can be traced to the legacy of post-conceptual Installation Art, which - from the 1960 s and 70s onwards - questioned systems of artistic value, resisted the commodification of the artwork and encouraged the active engagement of viewers in creative meaning making (Merleau-Ponty 1962; Bishop 2005). When drawn together, these discrete disciplinary trajectories can be seen to cut across each other in significant ways. The multiple "turns" and networks shaping this densely knotted relationship have blurred disciplinary boundaries and promoted experimentation outside the confines of familiar epistemic structures. Rather than simply expanding towards each other, archaeology, heritage and art have become increasingly entangled (Hawkins 2014, 5, after Krauss 1979). These processes are fluid, multivalent and ongoing. Listing even a small selection of the projects that occupy this critical space would take up the rest of this essay, but it is worth exploring two prominent examples here as a means of introducing the convergent territory that AHA investigates.

In 2013, the artist Daniel Silver created a site-specific installation in an abandoned plot of land on Grafton Way in central London. Centering on an assemblage of plaster cast figurines and statue fragments laid out as if just excavated, the work took inspiration from diverse reference points: archaeological sites the artist had visited as a child in Israel; the ethnographic collections of Sigmund Freud; kitsch tourist trinkets sold in Athens and Tuscany (Silver 2013a, 2013b). While it did not involve 
any close collaboration with archaeologists, Dig thus made manifest various strands contained in the concept of "the archaeological", from the uncanny atmosphere of the excavation to the metaphorical appropriations of the discipline by wider society (not least in terms of Freud's psychoanalysis - see Thomas 2004). By replicating the ways in which we manage and order the past in the present, both as material objects and psychological memories (Herkenhoff 2007, 84; Morton 2013), Dig opens up the multivalent processes of archaeology and heritage to renewed critical enquiry, drawing particular attention to the commodification of antique objects in the "dozens of parasitical gift shops" surrounding the nearby British Museum, selling massproduced replicas of unique artefacts (Cooke 2013). This evocation of the dig and antiquities trade addresses topics central to the work of archaeology and heritage, including the role of the object as a vector for cultural and personal identity formation. The entanglement of art, archaeology and heritage here is rooted in the claims all three make on the world, drawing on similar vocabularies and yet pointing towards often contrasting notions of "truth" and "reality".

Elizabeth Price's recent work A Restoration strikes a similar path, but straddles the disciplinary frames of archaeology, heritage and art even more effectively. Displayed at the Ashmolean Museum during Spring 2016, the artwork consisted of a film installation drawing on material from across the Ashmolean and Pitt Rivers Museum collections. This included photographs, sketches and frescoes from Knossos as well as a crystal glass depicting King Charles II of England hiding in the Boscobel Oak. Against a pulsing electronic soundtrack, rapid successions of images and text created a trance-like spectacle as Price led the viewer into "the back rooms of history" (Warner 2016): the digital files and administrative records that constitute the modern museum. A chorus of computerised female voices feature throughout, exposing the layered processes that go into collecting, conserving, processing and interpreting remnants of the past (Sumpter 2016, 109). This process sees the artist, antiquarian, archaeologist, curator and museum visitor become ever more entwined. As Marina Warner writes in a short essay accompanying the film, A Restoration "unleashes the forces inhering in mute things and issues a manifesto for thinking with art" (Warner 2016).

In contrast to Dig, this project involved the artist working within an institutional body for an extended period. Spending some two years investigating the two museum collections, Price discovered details that subsequently became integral to the final film. Learning, for example, that the clay fertility goddesses from Knossos were likely made to be broken, the artist juxtaposed photographs of these figurines with a soundtrack of short, sharp snapping sounds (Reindl 2014, 18; Warner 2016). In this, Price highlights a mismatch between ancient ideologies and contemporary museological attitudes. How can the museum, which prioritises conservation and completeness, approach objects that elude restoration? If the act of breakage is what gave these objects meaning, what does that mean for their treatment today? By questioning the processes at work in formulating approaches to the past in the present, A Restoration disrupts the museum as a site of knowledge creation, or - as the narrators intone at one point - as a "lovely, perverse refuge". This disruption is something that cuts across many examples of work at the nexus of archaeology and art, or heritage and art. Both artists evidently make a critical contribution across these fields; however, the question remains: can creative interventions like these only occasion temporary shifts in perception, or can they bring about lasting operational change in the practices and definitions of the collection/site/artefact (e.g. in 
cataloguing or conservation procedures)? Following Jorge Otero-Pailos, an artistarchitect who has been at the forefront of transdisciplinary research in recent years, one way to initiate such an ontological shift may be to encourage longitudinal engagement within individual working practices. He argues:

Architecture, preservation, art, and so on were all disciplines that were re-codified in the 19th century and accompanied the industrial revolution.

I think these disciplines are radically changing now into new ones, and so I'm perfectly comfortable with inhabiting all of them. It's our responsibility to move them into the new reality - the world we live in. (Otero-Pailos 2016)

\section{Archaeology/Heritage/Art: Re-Scripted Conversations}

It is in this context that the Archaeology/Heritage/Art Research Network has been established. Situated between and across these interconnected disciplines, the network aims to provide a space for the critical exploration of inventive and imaginative practices, inspired by similar initiatives at the crossroads of art and science, such as Arts Catalyst. Guided by our own research interests (the affective interrelationship of photography and heritage, sculptural interventions in the museum, diverse articulations of the curatorial within society), the network seeks to redirect and respond to the varied conceptual and methodological horizons offered by the creative turn(s). At the same time, it would be wrong to suggest there is any set agenda to the network. We do not aim to create specific artworks or dictate the kind of collaborations that might occur between practitioners in different fields. In this sense the project (if it can be labelled as such) is inherently experimental and process led: with each new activity or event, we learn a little bit more about what it is we are trying to achieve.

Perhaps the clearest line of enquiry to have emerged so far in our ongoing engagement with different art practices has been an exploration of the materialdiscursive environments in which knowledge systems are generated. By investigating both the Institute of Archaeology (IoA) and the Royal Institute of British Architects (RIBA) as distinctive buildings and social worlds, the network has sought to open up these authoritative disciplinary bodies to creative critical analysis. At the heart of this work has been a re-scripting of the Victorian "Conversazione" as a participatory apparatus. Echoing Otero-Pailos, this approach recalls a period before strict disciplinary boundaries, as a means of moving towards greater entanglement when addressing the realities of the contemporary world. How might this work in practice?

The term "Conversazione" refers to semi-public events held by learned societies across Britain during the nineteenth and early twentieth centuries to publicise their activities and provide a space for dialogue and debate (Hartrick 2008, 1). Part exhibition, part conference, part "show-and-tell", Conversazioni allowed for the display and discussion of technical endeavours alongside historic and/or artistic material collected by contributors. Crucially, amateurs and emerging professionals shared a platform at such events, and were actively encouraged to participate as visitors, exhibitors and lecturers. Almost every branch of learning embraced the Conversazione, with local and national institutions hosting events focused on subjects such as architecture, ethnography and the natural world (Hartrick 2008, 1). The Royal Society Conversazione of 1903 for example included some 46 exhibits, ranging from "Photographs Illustrative of the Coronation Naval Review, 1902" to a display on "The Condensation of the Radioactive Emanations of Radium and Thorium by Liquid Air" (Royal Society 1903). 
What can be learnt from the Conversazione as an earlier space of interdisciplinary exchange? First, it is important to note that the very concept of "disciplinarity" would have been alien to those organising or attending such events. While the emergence of the Conversazione coincided with the expansion of learned societies focused on specific subjects (such as archaeology and architecture), the membership and activities of these groups were fluid. An esteemed expert in one field might play an integral part in the establishment of another. The celebrated scientist Michael Faraday, for example, was a contributor to the RIBA; indeed, this same institution played host to many talks and events focused on archaeological research throughout the nineteenth century. This fusion of specialist and dilettante inquiry was a distinguishing trait of the Conversazione, and one that we have found to be a useful and refreshing model for collaboration across art, archaeology and heritage. We have also found, however, that its key practitioners do not appropriate one another's expertise and practices wholesale, but rather remain open to the benefits of approaching the same questions from different and/or multiple perspectives. The informality of the Conversazione encouraged independent interpretation by visitors and participants while offering space for personal engagements with objects, artworks and ideas destined to be subsumed by broader categories and institutional bodies. For artists and archaeologists working today, such open, process-led environments are invaluable, providing opportunities to work beyond formal, outcome-oriented projects and move towards ongoing interdisciplinary practice along unexpected research avenues. There are similarities here with the experimental workshops now common to collaborations between artists and scientists, where different lenses are brought to bear on the same subject (see projects at CAST, the MIT Center for Art, Science and Technology, for example). However, what marks the Conversazione out is its commitment to a democratic environment of shared display and storytelling - a model that takes us away from impact-led agendas and towards critical, reflexive and open-ended participation (for an insightful critique of participatory art practice see Bishop 2012). Leaving aside concerns about how far Conversazioni of the nineteenth century were truly "democratic", what we want to emphasise is the potential for old practices to create new opportunities for - in the words of Otero-Pailos - "inhabiting" different disciplines all at once. If the Victorian Conversazioni helped to ferment an academic environment in which positivist conceptualisations of the world could take hold, might a re-scripted version of such events actually help break down barriers of knowledge making, as well as sharing? Of course, the terms "archaeology", "heritage" and "art" are all extremely broad, and we would not want to delimit the scope of their critical horizons, but it is telling that creative interactions across the three commonly congregate at points of communication, interpretation and display. The fields share a participatory language of dissemination and generate creative exchanges through these corresponding channels. The Conversazione format suits just such an interdisciplinary exchange, by creating dialogue through these three points of convergence: that is, display, the communication of new ideas and encouraging audiences to reach independent interpretations of material.

Within the (loose) agenda of the AHA Research Network, the bene ts of this approach have been noteworthy. Across three separate events held at the IoA and the RIBA, the disciplinary structures and material spaces of these established organisations have been subverted, and their rigid social worlds collapsed. The events have seen established academics, early career researchers, students at all 
levels and administrative staff present and discuss their own creative practices and consider the wider disciplinary environments in which they operate. This has allowed for alternative perspectives on the notion of artistic, curatorial or archaeological disciplinarity to emerge, with things - everyday objects, administrative records, personal artefacts and original artworks - giving rise to creative points of intrigue. The display of the last remaining 1940 s stool from the former IoA Library (at St John's Lodge, Regent's Park), for instance, elevated a quotidian item to the status of art-historical object (Ran 2009). Performing an "archaeology of" the British Architectural Library meanwhile offered opportunities to approach the space as an environment affected by, and open to, different institutional narratives and reverberations. The performative nature of these enquiries is vital to their critical efficacy, which emerges not from the products displayed, but from the ephemeral, sensory and embodied engagements of the event.

The Conversazione thus provides a useful space for drawing out embedded creative attitudes and artistic practices within disciplinary environments. For instance, our inaugural Conversazione was centred around an exhibition of photographs, sculptures and other artworks created by, or in collaboration with, staff and students from the IoA. By showcasing these creative products, the event revealed a substratum of individuals within the disciplinary community for whom art and/or artistic practice informs their archaeological work, but is not expressed or acknowledged in their formal research outputs. This event also raised departmental awareness of ongoing, expressly interdisciplinary art/archaeology and art/heritage projects, and encouraged informal discussion and idea sharing between participants. Indeed, out of the Conversazioni have emerged a number of collaborative projects between archaeologists and contemporary artists, investigating themes as diverse as migration and colour theory.

For us, the crucial realisation has been that the Conversazione format need not be a programmatic initiative towards transdisciplinarity. By being an open and participatory forum, it can uncover instinctive, unconscious and/or self-determined interdisciplinary entanglements. Indeed, the Research Network has revealed another set of embedded processes: those tied up in and affecting the interdisciplinary relationship at the heart of AHA. Working closely together as joint network coordinators has drawn out our different theoretical and research backgrounds, and forced us to look beyond the familiar "horizons of our existing knowledge and practices" (Hawkins 2014, 246). This has led to an exchange of approaches across critical heritage and public archaeology, which has both extended the creative possibilities of the network and had an important re exive impact on us as individual researchers, shaping new curatorial exercises and attitudes towards audience engagement, for example. The future direction of the network will build upon this cross-disciplinary outlook.

\section{Conclusion}

A critical efficacy characterises many of the best examples of research and practice carried out under the rubric of the "creative turn". Art in these contexts is to be understood as much more than a new interpretive apparatus or alternative means of communicating or visualising the past in the present. Conceptually and methodologically engaged, art can become a transformative force for archaeology and heritage (Hawkins 2014, 2). To achieve this potential demands sustained engagement between archaeologists, heritage professionals and artists, built around 
shared questions and iterative research agendas. Beyond this, new spaces and a breakdown of disciplinary structures are also required to ferment meaningful practice. It is in these fluid, liminal spaces between and beyond familiar subject boundaries that we have identified new conceptual possibilities and opportunities for experimentation. The model of the Conversazione demonstrates the benefits of remaining fluid rather than fixed, even when returning to an historical precedent. From the outset, a key touchstone for AHA has been John Carey's belief that art is at its most meaningful and substantive when it is "done, not consumed, and done by ordinary people, not master-spirits" (Carey 2006, 152). For the archaeologist or heritage professional, this is heartening, effectively circumventing the need for all creative work that might be undertaken within these fields to be groundbreaking. It is more important that art become part of the toolkit of the archaeologist, the cataloguer, the conservator, the curator, rather than restricted to the artist. Indeed, it has been a core contention of this paper that such labels should be dissolved as the creative turn(s) move forward. Where possible, we need to inhabit one another's perspectives, not simply collaborate on shared questions and projects (although this remains an important step in opening up new lines of enquiry).

Framed by a discussion of the activities and manifesto of the AHA Research Network, our response has expressed the importance of the transdisciplinary relationship encapsulated by this forum. We appeal for more projects that embrace uncertainty and experimentation across archaeology, heritage and art. We also suggest that the terms "creative turn" and "creative archaeologies" do not sufficiently represent the possibilities of interdisciplinary entanglement, and wonder if, like the dissolving of disciplinary boundaries, this activity need not be restrained by a specific label. A continuous process of exchange sits at the heart of successful artarchaeology-heritage collaborations, and while the limitations of this feedback loop need to be acknowledged, steps towards a destabilisation of familiar epistemic structures can still be made. Returning to Barthes, it is through this fluidity - this "unease in classi cation" - that truly interdisciplinary activities and practices can be performed (Barthes 1977, 155).

Within this milieu, probing artistic work such as that of Daniel Silver and Elizabeth Price should continue to be created, especially as it shows how concepts and practices can cross-fertilise different approaches to the world. However, there is a pressing need for a wider, transdisciplinary provision of roles, practices and material-discursive environments to help drive forward this participatory agenda. Archaeology, heritage and art are liable to become ever more entangled under such circumstances, perhaps to the point where the disciplines themselves disappear. We suggest that this uncertainty should be grasped and celebrated by scholars and practitioners as an opportunity to follow unexpected research trajectories, explore new territory outside common subject narratives, and create fresh, radical and exciting work.

\section{Acknowledgements}

Thanks to Dr Beverley Butler, Dr Jonathan Gardner, Prof. Rodney Harrison, Dr Mark Lake, Dr Gabriel Moshenska, Dr Amara Thornton and the IoA Heritage Section as committed supporters of the AHA Research Network. 


\section{DRAFT COPY}

\section{References}

Barthes, R. 1977. Image Music Text. Translated by S. Heath. London: Flamingo.

Bishop, C. 2005. "But is it Installation Art?” Tate Etc 3 (Spring). Available online: http://www.tate.org. uk/context-comment/articles/it-installation-art. 2012. Artificial Hells: Participatory Art and the Politics of Spectatorship. London and New York: Verso Books.

Carey, J. 2006. What Good are the Arts? Oxford: Oxford University Press.

Cooke, R. 2013. "Artangel/Daniel Silver: Dig Review.” The Guardian, 15 September. Available online: https://www.theguardian.com/artanddesign/2013/sep/15/danielsilver-dig-artangel-review

Graves-Brown, P., R. Harrison and A. Piccini.2013. “Introduction.” In The Oxford Handbook of Archaeology of the Contemporary World, edited by P. Graves-Brown, R. Harrison and A. Piccini, 1-26. Oxford: Oxford University Press. https://doi. org/10.1093/oxfordhb/9780199602001.001.0001

Harrison, R. 2015. "Beyond 'Natural' and 'Cultural' Heritage: Toward an Ontological Politics of Heritage in the Age of the Anthropocene." Heritage \& Society 8 (1): 24-42. https://doi.org/10.1179/215 9032X15Z.00000000036

Hartrick, E. 2008. "Curiosities and Rare Scientific Instruments: Colonial Conversazioni in Australia and New Zealand in the 1870 s and 1880s." In Seize the Day: Exhibitions, Australia and the World, edited by K. Darian-Smith, R. Gillespie, C. Jordan and E. Willis, 11.1-11.19. Victoria: MONASH University ePress. Available online: http://books.publishing.monash.edu/apps/

bookworm/view/SEIZE+THE+DAY/123/xhtml/ chapter11.html

Hawkins, H. 2014. For Creative Geographies: Geography, Visual Arts and the Making of Worlds. Lon- don and New York: Routledge.

Herkenhoff, P. 2007. “The Dyslexic Sculpture of Daniel Silver." In Daniel Silver, by P. Herkenhoff and A. Robinson, 83-90. Manchester: Cornerhouse Publishing.

Krauss, R. 1979. "Sculpture in the Expanded Field." October 8: 30-44. https://doi. org/10.2307/778224

Merleau-Ponty, M. 1962. Phenomenology of Perception. Translated by C. Smith. London and New York: Routledge.

Morton, T. 2013. Untitled essay. In Dig, by D. Silver and edited by J. Lingwood, 8596. London: Artangel.

Otero-Pailos, J. 2016. "Ritual Evidence.” Architect Magazine, 7 March. Available online: http://www. architectmagazine.com/aia-architect/aiafeature/ ritualevidence_o

Royal Society. 1903. Conversazione June 19th 1903. London: Burlington House. 


\section{DRAFT COPY}

Ran, F. 2009. A History of Installation Art and the Development of New Art Forms: Technology and the Hermeneutics of Time and Space in Modern and Postmodern Art from Cubism to Installation. New York: Peter Lang. https://doi. org/10.3726/978-1-4539-0587-6

Reindl, U. M. 2014. “Elizabeth Price.” EIKON 88: 4-19.

Russell, I. A. 2013. "The Art of the Past: Before and After Archaeology.” In The Way of the Shovel: On the Archaeological Imaginary in Art, edited by D. Roelstraete, 296313. Chicago: University of Chicago Press.

Silver, D. 2013a. "Can You Dig It? Artist Daniel Silver on New Artangel Commission." Evening Standard, 29 August. Available online: http://www.standard.co.uk/goingout/exhibitions/can-you-dig-it-artist-danielsilver-on-new-artangel-commis- sion-8788978.html

Silver, D. 2013b. "Daniel Silver in Conversation with James Lingwood." Available online: https://www. artangel.org.uk/dig/daniel-silver-in-conversation- with-jameslingwood/

Sumpter, H. 2016. "Elizabeth Price: A RESTORATION: Ashmolean Museum, Oxford 18 March - 15 May A PROCESSION: Pitt Rivers Museum, Oxford 18 March - 29 May." Art Review 68 (4): 109.

Thomas, J. 2004. Archaeology and Modernity. Lon- don and New York: Routledge.

Warner, M. 2016. "A Restoration: An Essay by Marina Warner.” Available online: http://www.ash- molean.org/exhibitions/arestoration/essay/

Waterton, E. and S. Watson. 2014. The Semiotics of Heritage Tourism. Bristol, UK: Channel View Publications.

Wickstead, H. 2013. "Between the Lines: Drawing Archaeology.” In The Oxford Handbook of Archaeology of the Contemporary World, edited by P. Graves-Brown, R. Harrison and A. Piccini, 549- 564. Oxford: Oxford University Press. https://doi. org/10.1093/oxfordhb/9780199602001.013.012

Leah Acheson Roberts is a PhD student at UCL Institute of Archaeology. Address for correspondence: Institute of Archaeology, University College London, 31-34 Gordon Square, Kings Cross, London WC1H oPY.

Colin Sterling is a Postdoctoral Research Associate at the Institute of Archaeology, University College London. Address for correspondence: Institute of Archaeology, University College London, 31-34 Gordon Square, Kings Cross, London WC1H oPY. 